\title{
Utilization of Telescopium Mussel Meal as an Alternative Protein Source in the Diet of Black Tiger Shrimp, PENAEUS MONODON
}

\author{
Agus Kurnia $^{1}$, Wellem H. Muskita ${ }^{2}$, Oce Astuti ${ }^{3}$, Adnan Hakim ${ }^{4}$ \\ ${ }^{1,2,3}$ Department of Aquaculture, Faculty of Fisheries and Marine Science, Halu Oleo University \\ ${ }^{4}$ Department of Management, Faculty of Economy and Business, Halu Oleo University
}

Office Address : Department of Aquaculture, Faculty of Fisheries and Marine Science, Halu Oleo University, Kampus Bumi Tridharma, Anduonohu Kendari Southeast Sulawesi, Indonesia 90212

\begin{abstract}
The utilization of telescopium mussel meal (TMM) as a substitute for fish meal (FM) was evaluated in black tiger shrimp (initial weight: $0.0134 \pm 0.02$ ) diets containing five levels of TMM (from 0 to $100 \%$ ). After 42 days, live weight averages were $0.37,0.33$, $0.29,0.27$ and $0.24 \mathrm{~g}$ for fish fed diet in which $\mathrm{FM}$ was substituted with 100, 75, 50, 0 and 25\% TMM, and feed conversion ratios were 3.20, 3.05, 4.01, 3.65 and 4.46, respectively. No differences were obtained in weight gain, FCR, FE and SR for all treatments. The shrimp fed diet $\mathrm{E}(100 \% \mathrm{TMM})$ was highest in FE and followed by the shrimp fed diet D (75\% TMM), diet C (50\% TMM), diet B (25\% TMM) and diet A( $0 \%$ TMM), respectively. SR was highest in the shrimp fed diet A and the lowest was found in the shrimp fed diet $D$. This study concluded that TTM could replace FM up to $100 \%$ in the diet without compromising growth and feed efficiency of black tiger shrimp larvae.
\end{abstract}

Keywords: Fish meal; Telescopium mussel meal; Substitute fish meal; Black tiger shrimp larvae

\section{Introduction}

Most of the problem in intensive culture is feed management because it can require around $40-60 \%$ of total production cost of shrimp culture. The big percentage of feed ingredients is fish meal around $30-60 \%$ of formulated diet ingredients. Fish meal is one of the primary proteins used in fish feeds, because of its known nutritional and palatability characteristics. Beside that fish meal is known also as an expensive ingredient. Fish meal (FM) is considered the most desirable animal protein ingredient in aquaculture diets because of its high protein content, balanced amino acid profiles, high digestibility and palatability, and as a source of essential $n-3$ polyenoic fatty acids. However, FM is one of the most expensive macro-ingredients (used in high percentages) in an aquaculture diet. Likewise, with the static or declining fish populations that are used to produce FM, the view held by some is that the use of FM in aquaculture diets is wasteful and unethical. The high cost of FM and concerns regarding its future availability have made it imperative for the aquaculture industry to reduce or eliminate FM from fish and crustacean diets.

The demand for fish feeds is rising by some 5\% a year because production from aquaculture is rising. Nevertheless, the supply of this ingredient cannot increase and prices have increased to a historic high level. In order to sustain aqua feed industry, a great part of nutritional research has been focused on the search for alternative proteins to replace fish meal with more economical protein sources. One of the most potential as an alternatives protein sources is telescopium mussel meal.

Telescopium mussel (TM) is a gastropoda which large distributed and found in mangrove and shrimp ponds area. In
Indonesian, telescopium mussel is called as temberungan" or burungo", while in Irian, it is well known as - pi". The mussel is till now considered as a mother" of parasite and competitor organism for shrimp culture. Therefore it caused decreasing production of mostly intensive shrimp. Information of utilization of this protein source as ingredient in fish feed is still limited. Iromo and Kurnaen (2012) suggested that telescopium meat could be fed to obtain optimum growth of mud crabs. These mussel has economical value and are consumed as dishes, and also has the advantage as asthma medicine. Irian people eat this mussel for food and in the market, the price of this mussel is variance between 10.000 IDR - 25.000 IDR.

The present study was conducted to assess the effect of using telescopium meal as ingredients based on percentage of replacement with fish meal practical feeds on the growth and survival rate of monodon shrimp larvae.

\section{Materials and Methods}

- Feed formulation and preparation

Telescopium meal and FM were bought from some traditional fish markets in Kendari, Southeast Sulawesi Indonesia with the price were $\mathrm{Rp} 10.000 / \mathrm{kg}$ and $\mathrm{Rp}$ $45000 / \mathrm{kg}$, respectively. Some telescopium mussel were collected from shrimp pond for free around Moramo, in the eastern of Kendari City . Other feed ingredients such as sago meal, corn meal, brain rice meal, fish oil, and top mix (combination vitamins and minerals mix) were obtained from a shop farm company. The proximate composition of the FM and TM are presented in Table 1, while the amino acid composition of telescopium is presented in Table 2 . 


\section{International Journal of Science and Research (IJSR) \\ ISSN (Online): 2319-7064 \\ Index Copernicus Value (2013): 6.14 | Impact Factor (2014): 5.611}

The five experimental feeds were formulated to contain decreasing amounts of FM and increasing amounts of TMM. The ingredient compositions of the diets are presented in Table 3. Diet A was formulated to be similar to a commercial high-quality finfish diet containing $0 \mathrm{~g} . \mathrm{kg}^{-1} \mathrm{TM}$ and $550 \mathrm{~g}$ $\mathrm{kg}-1$ sarden FM (100\% FM); diet B contained $137.5 \mathrm{~g} \mathrm{~kg}-1$ TMM and $412.5 \mathrm{~g} \mathrm{~kg}^{-1}$ (25\% TMM:75\% FM), diet C contained $225 \mathrm{~g} \mathrm{~kg}$ TMM and $225 \mathrm{~g} . \mathrm{kg}{ }^{-1} \mathrm{FM}$ (50\% TMM: $50 \% \mathrm{FM})$; diet D contained $412.5 \mathrm{~g} \mathrm{~kg}^{-1} \mathrm{TMM}$ and $137.5 \mathrm{~g}$ $\mathrm{kg}^{-1}$ FM (75\% TMM: 25\% FM) and diet E contained 550 g. $\mathrm{kg}^{-1} \mathrm{TM}(100 \% \mathrm{TM})$. Five dry feeds were formulated to contain non isonitrogenous because of the formulated diet based on different percentage of replacement FM and TM without analyzing of major feed ingredients before, including proximate content of TM. Sixth feed was commercial diet and this feed served as a comparison to the formulated feeds. Because of the differences in proximate com- position of the dietary ingredients from tabular values (NRC 1993), diets varied somewhat in actual chemical analysis from calculated values. The formulation and chemical composition of the test feeds are presented in Table 3.

The dry ingredients were ground with a hammer grinder, passed through a $0.5 \mathrm{~mm}$ sieve, and mixed in a $30-1$ kitchen mixer. Slow sinking pellets were made using a laboratoryscale. The pellets (diameter $4 \mathrm{~mm}$ and length $8 \mathrm{~mm}$ ) were cooled and dried at room temperature.

\section{- Diet Analysis}

Diets were analyzed to determine percentage moisture, protein, lipid, fibre and ash. Moisture was determined by placement of a 2 -g sample into a convection oven $\left(135^{\circ} \mathrm{C}\right)$ for $2 \mathrm{~h}$ until constant weight was achieved (AOAC 1995; procedure 930.15); protein was determined by the Kjedahl method (AOAC 1995; procedure 990.03); lipid was determined by soxhlet method (AOAC 1995; procedure 954.02); fibre was determined by using the fitted-glass crucible method (AOAC procedure 962.09) and ash was determined by placing a $2 \mathrm{~g}$ sample in a muffle furnace $\left(600^{\circ} \mathrm{C}\right)$ for $6 \mathrm{~h}$ (AOAC 1995; procedure 942.05).

Table 1. Proximate composition of the FM and TMM

Table 2. Amino acid composition of TMM

Table 3. Formulation and chemical composition of the test feeds.

\section{- Fish, husbandry and feeding}

An 6-week feeding trial was carried out in hatchery belong to Department of Marine Affairs and Fisheries Kendari, Southeast Sulawesi, Indonesia. Black tiger shrimps larvae obtained from that hatchery and originally come from one broodstock. Two weeks prior to the trial, 1080 shrimp larva were distributed and reared in 18 experimental strerefoam boxes $(60 \times 30 \times 45 \mathrm{~cm})$ at 60 fish per box, during the acclimation the fish were fed the control feed twice daily. The start of the trial, the acclimated fish were deprived of feed for $24 \mathrm{~h}$, pooled, and 18 groups each of 40 shrimp larva were weighed, and randomly stocked into 18 experimental boxes, with 3 replication of each treatment.

During the trial, the shrimp were hand fed five times at 06.00, 10.00, 14.00, 18.00 and $22.00 \mathrm{~h}$ daily. Dead shrimp were replaced throughout the experiment with tagged shrimp from the reserve tanks to avoid density dependent effects but no measurements were made on replacement shrimp. Shrimp in reserve tanks were fed corresponding experimental diets prior to being introduced into experimental tanks. During the experiment, each shrimp in one tank was assumed to consume an equal amount of offered feed. Excess feed remaining on the bottom of the tanks was siphoned out $4 \mathrm{~h}$ after feeding, collected, pooled, and dried for the determination of the amount of feed consumed. The percentage of dry matter retained for each diet immersed in seawater for $4 \mathrm{~h}$ was used as a correction factor for calculation of the total estimated feed intake. Sampling was conducted once in 14 days to measure the weight gains of shrimp larvae. The quality of diets was evaluated in terms of daily growth rate mg.day ${ }^{-1}$ shrimp, feed efficiency (g/shrimp), feed conversion ratio (FCR) and percent survival (\%) (Cho et al.,1985).

\section{- Statistical Analysis}

Data were analysed by analysis of variance (ANOVA) using the SASSAS General Linear Models (GLM) procedure (SASSAS software version 8.2; SAS 1999) to determine whether growth was significantly different among treatment means. Significant differences between means were separated by Duncan's multiple range test. All percentage and ratio data were transformed to arc sin values prior to analysis (Zar 1984). All statistical computations were performed at the $\mathrm{P} \quad 1 / 40.05$ probability level. Data are presented as untransformed values. Multiple regressions were with growth and production parameters (such as weight gain percentage, SGR, FCR, survival rate as dependent variables, and (1) diet type or (2) telescopium meal content in diets as independent variables.

\section{Results}

\section{- Water Quality}

Average monthly morning water temperature ranged from $28.2{ }^{\circ} \mathrm{C}$ in to $29.6{ }^{\circ} \mathrm{C}$. Dissolved oxygen levels averaged 6.8 $-7.3 \mathrm{mg} . \mathrm{L}^{-1}$. and $\mathrm{pH}$ averaged $8.6 \pm 0.3$ for the duration of the study, and these averages were within acceptable values for growth of fish (Boyd 1979).

\section{- Growth and Production}

At the conclusion of the feeding trial, there were no significant $(\mathrm{P}>0.05)$ differences in mean final weight, percentage weight gain, SGR and FCR among treatments. Absolutely growth was obtained in average ranged between $0.25 \mathrm{~g}$ to $0.38 \mathrm{~g}$. The highest of absolutely growth was observed in the shrimp fed diet E (100\% TM) and the lowest one was observed in shrimp fed diet B (75\% FM : 25\% TM) (Fig.1). While, the FCR was found in average ranged between 1.71 to 2.65 . The lowest of FCR was found in the shrimp fed diet $\mathrm{E}$ and the highest one was found in the shrimp fed diet B (fig. 2). In the figure 3 showed that the highest of survival rate was observed in the shrimp fed diet A $(63.5 \%)$ and followed by the shrimp fed diet B (58.3\%), shrimp fed diet F (56.9\%), the shrimp fed diet C (55.0\%), the shrimp fed diet D (46.9\%) and the lowest one was the shrimp fed diet E (46.4\%), respectively. 


\section{International Journal of Science and Research (IJSR) \\ ISSN (Online): 2319-7064 \\ Index Copernicus Value (2013): 6.14 | Impact Factor (2014): 5.611}

\section{Discussion}

The main finding of these studies was that the species of telescopium used in artificial diets and the nature of the dietary telescopium meal ingredients affected utilization of diets by juvenile shrimp, $P$. monodon. Totally replacement of fish meal with telescopium meal diet gave better performance compared to all other diets except for survival rate of shrimp. The absence of significant differences in daily growth rate feed intake, FCR, survival, between shrimp fed all treatment diet present study indicates that the nutritive value of telescopium meal meal derived from dehulled telescopiium telescopium species is comparable to that of fish meal for juvenile $P$. monodon. Thus, there is a possibility of using telescpoium meal as an alternative protein source for fish meal in artificial feeds for $P$. monodon at above $45 \%$ inclusion level as a replacement of $30 \%$ of telescopium meal on an equal protein basis.

When data from this research are used to calculate specific growth rate measures in $\mathrm{mg} /$ day, comparisons can be made between the results obtained in this study and those previously reported in another penaeid species. Using this experimental diet, the best of specific growth rate of $P$. monodon was obtained an average $7.8 \mathrm{mgr} /$ day on the best performing diets diet $\mathrm{E}$ in the present study was comparable to that reported for similar sized penaeids fed artificial diets in laboratory tanks. Results in this study was higher than Results obtained from the research conducted from Harter et al (2011) suggested that the shrimp fed diet fish meal only obtained SGR in $3.18 \mathrm{mg} /$ day.

Some animal protein sources such as poultry by-product meal (PBM) and meat $\mathrm{MBM}$ as protein alternates are suitable protein ingredients in properly formulated diets for white shrimp (Davis \& Arnold 2000; Forster et al. 2003; Cruz-Suarez et al.2007) and red claw crayfish (Saoud et al. 2008). However, very high or the complete replacement of FM with these protein ingredients in practical diets for crustaceans, in particular with white shrimp, has been less successful under laboratory conditions (Forster et al. 2003; Hernandez et al. 2004, 2008; Cruz-Suarez et al. 2007). Some research results have shown that FM can be completely replaced by terrestrial rendered by-products and plant protein sources alone or by a blend without adverse effects on growth and survival.

A combination of scallop waste and shrimp head meal (Sudaryono et al. 1995), co-extruded soybean poultry byproduct meal with egg supplement (Samocha et al. 2004), SBM with brewer's grains (Muzinic et al. 2004), a combination of plant protein ingredients (Thompson et al. 2005) or SBM alone (Amaya et al. 2007b) without FM addition in practical diets can be effectively fed to various shrimp species. Guo et al. (2007) stated that combination of various rendered animal ingredients may be more adequate in nutritional value for cuneate drum than the use of the ingredients alone. To make up for a single ingredient deficiency in nutrients, and to improve the nutritional values of alternate protein sources, complementary protein sources to replace FM in practical diets was adopted through a combination of three rendered animal by-products and a plant protein ingredient using a specific formulating proportion for the present study. The dietary inclusion of a mixture significantly affected the growth response of white shrimp at each dietary protein level. There was a trend of reduced growth with increasing the mixture in diets, and significant growth retardation of the white shrimp was observed at the higher level of FM replacement $(714 \mathrm{~g} \mathrm{~kg}) 1$ FM for 330 g.kg ${ }^{-1}$ protein level and $784 \mathrm{~g} \mathrm{~kg}^{-1}$ for $380 \mathrm{~g} \mathrm{~kg}$ protein level, respectively) compared with those of the control. This is consistent with the results by Forster et al. (2003) and Hernandez et al. (2008), who used MBM as single protein replacement for FM.

In the present study, the crude protein level of the diet was 400 g.kg-1 to 460 g.kg-1, it was higher compared to the some previous studies. In the previous studies showed that the appropriate protein level in practical diets for white shrimp is between 300 and $350 \mathrm{~g} \mathrm{~kg}^{-1}$ (Cuzon et al. 2004). However, the resulting value was renewed to exceed the upper limit range indicated in some current research reports (Goytortu' a-Bores et al. 2006; Venero et al. 2007; Suarez et al. 2009), and this shrimp needs higher CP level in highsalinity water (Zhu et al. 2009). This suggests that white shrimp requires higher-dietary protein level than is usually considered before either in laboratory rearing system or in ponds. This was confirmed by our present result that white shrimps fed a $380 \mathrm{~g} \mathrm{~kg}$ )1 CP diet could grow faster than those fed a $330 \mathrm{~g} \mathrm{~kg}) 1 \mathrm{CP}$ diet at any FM replacement level. The results were further supported by Smith et al. (1985), who pointed that optimal growth for white shrimp was significantly influenced by dietary protein level.

The results of this study indicate that Telescopium meal could be utilized as a protein source and can replace up to $100 \%$ of fish meal in diets of $P$. monodon. Further work to evaluate the efficacy telescopium meal as alternative protein sources for fish meal in diets for growing $P$. monodon in pond conditions should be addressed.

\section{Acknowledgment}

I would like to give many thanks for Directorate General of Higher Education of Indonesia which has given funding for this research (STRANAS DIKTI). Also, I would like to give great thanks for Tokyo University of Marine Science and Technology which has given us good facilities to analyze our samples.

\section{References}

[1] Amaya, E., Davis, A. \& Rouse, D. (2007b) Replacement of fish meal in practical diets for the Pacific white shrimp (Litopenaeus vannamei) reared under pond conditions. Aquaculture, 262, 393-401.

[2] AOAC (1995) Official Methods of Analysis, 16th edn. Association of Official Analytical Chemists (AOAC), Arlington, VA, USA.

[3] Boyd, C.E. (1979) Water quality in Warmwater Fish Ponds. Auburn University Agricultural Experiment Station, Auburn, AL, USA.

[4] Cho, C.Y., Cowey, C.B., Watanabe, T., 1985. Finfish Nutrition in Asia: Methodological Approaches to Research and Development. IDRC, Ottawa, Ontario. 


\section{International Journal of Science and Research (IJSR) \\ ISSN (Online): 2319-7064 \\ Index Copernicus Value (2013): 6.14 | Impact Factor (2014): 5.611}

[5] Cruz-Suárez, L.E., Ricque-Marie, D., Tapia-Salazar, M., McCallum,I.M., Hickling, D., 2001. Assessment of differently processed feed pea (Pisum sativum) meals and canola meal (Brassica sp.) in diets for blue shrimp (Litopenaeus stylirostris). Aquaculture 196 (1-2), 87104.

[6] Davis, D.A., Arnold, C.R., 2000. Replacement of fish meal in practical diets for the Pacific white shrimp, Litopenaeus vannamei. Aquaculture 185, 291-298.

[7] Forster, I., 1999. A note on the method of calculating digestibility coefficients of nutrients provided by single ingredients to feeds of aquatic animals. Aquaculture Nutrition 5, 143-145.

[8] Goytortu' a-Bores, E., Civera-Cerecedo, R., RochaMeza, S. and Green-Yee, A. (2006) Partial replacement of red crab (Pleuroncodes planipes) meal for fish meal in practical diets for the white shrimp Litopenaeus vannamei. Effects on growth and in vivo digestibility. Aquaculture, 256, 414-422

[9] Guo, J., Wang, Y. \& Bureau, D.P. (2007) Inclusion of rendered animal ingredients as fishmeal substitutes in practical diets for cuneate drum, Nibea miichthioides (Chu, Lo et Wu). Aquac. Nutr., 13, 81-87.

[10] Harter, T., Buhrke, F., Focken, U., Makkar, H.P.S. 2011. Substitution of Fish Meal by Jatropha Curcas Kernel Meal: Effects on Growth Performance and Body Composition of White Leg Shrimp (Litopenaeus vannamei). Aquaculture Nutrition, 17 : 542-548.

[11]Hernandez, C., Sarmiento-Pardo, J., GonzalezRodriguez, B. \&Abdode la Parra, I. (2004) Replacement of fish meal with co-extruded wet tuna viscera and corn meal in diets for white shrimp (Litopenaeus vannamei, Boone). Aquacult. Res., 36, 834-840.
[12] Muzinic, L.A., Thompson, K.R., Morris, A., Webster, C.D., Rouse, D.B. \& Manomaitis, L. (2004) Partial and total replacement of fish meal with soybean meal and brewer's grains with yeast in practical diets for Australian red claw crayfish Cherax quadricarinatus. Aquaculture, 230, 359-376.

[13] Samocha, T.M., Davis, D.A., Saoud, I.P., DeBault, K., 2004. Substitution of fish meal by co-extruded soybean poultry byproduct meal in practical diets for the Pacific white shrimp, Litopenaeus vannamei. Aquaculture 231, 197-203.

[14] Smith, L.L., Lee, P.G., Lawrence, A.L. \& Strawn, K. (1985) Growth and digestibility by three sizes of Penaeus vannamei Boone: effects of dietary protein level and protein source. Aquaculture, 46, 85-96.

[15] Suarez, J.A., Gaxiola, G., Mendoza, R., Cadavid, S., Garcia, G.,Alanis, G., Suarez, A., Faillace, J. \& Cuzon, G. (2009) Substitution of fish meal with plant protein sources and energy budget for white shrimp Litopenaeus vannamei (Boone, 1931). Aquaculture, 289, 118-123.

[16] Sudaryono, A., Hoxey, M.J., Kailis, S.G., Evans, L.H., 1995. Investigation of alternative protein sources in practical diets for juvenile shrimp Penaeus monodon. Aquaculture 134, 313-323p

[17] Tacon, A.G.J., 1987. The Nutrition and Feeding of Farmed Fish and Shrimp-A Training Manual 1. The Essential Nutrients. FAO of the United Nations, Brazil.

[18] Thompson, K.R., Muzinic, L.A., Engler, L.S. \& Webster, C.D. (2005) Evaluation of practical diets containing different protein levels, with or without fish meal, for juvenile Australian red claw crayfish (Cherax quadricarinatus). Aquaculture, 244, 241- 249.

[19]Zar, J.H. (1984) Biostatistical Analysis. Prentice-Hill, Englewood Cliff, NJ.

Table 1: Proximate composition of the FM and TMM

\begin{tabular}{|c|c|c|}
\hline Parameters (\%)* & FM & TMM \\
\hline Moisture & 8.50 & 9.64 \\
\hline Crude Protein & 69.9 & 67.6 \\
\hline Crude Lipid & 11.1 & 6.35 \\
\hline Ash & 6.81 & 7.72 \\
\hline
\end{tabular}

Note: The ingredients were analyzed in Laboratory of Fish Nutrition in Tokyo University of Marine Science and Technology, Japan

Table 2: Amino acid composition of TMM

\begin{tabular}{|c|l|l|}
\hline No & Amino Acid (\%) & Level \\
\hline 1. & Aspartat acid & 2.69 \\
\hline 2. & Glutamate acid & 3.97 \\
\hline 3. & Serine & 0.90 \\
\hline 4. & Glycine & 2.01 \\
\hline 5. & Histidine & 1.35 \\
\hline 6. & Arginine & 1.53 \\
\hline 7. & Threonine & 0.82 \\
\hline 8. & Alanine & 0.79 \\
\hline 9. & Proline & 2.85 \\
\hline 10. & Tyrosin & 1.10 \\
\hline 11. & Valine & 0.72 \\
\hline 12. & Metionine & 0.91 \\
\hline 13. & Sistein & 0.79 \\
\hline 14. & Iso-leucine & 1.42 \\
\hline 15. & Leucine & 1.73 \\
\hline 16. & Phenyl alanine & 0.84 \\
\hline 17. & Lysine & 2.12 \\
\hline
\end{tabular}

Note: The amino acid composition of TMM was analyzed in Laboratory of Animal science in Bogor Agriculture University, Indonesia 


\section{International Journal of Science and Research (IJSR) \\ ISSN (Online): 2319-7064}

Index Copernicus Value (2013): 6.14 | Impact Factor (2014): 5.611

Table 3: Ingredients and diet formulation of experimental diet

\begin{tabular}{|c|cccccc|}
\hline Ingredients & \multicolumn{7}{c|}{ Diet $(\mathrm{g} / 100 \mathrm{~g})$} \\
\hline & $\mathrm{A}$ & $\mathrm{B}$ & $\mathrm{C}$ & $\mathrm{D}$ & $\mathrm{E}$ & $\mathrm{F}$ \\
\hline Fish meal & 55 & 41,25 & 27,5 & 13,75 & 0 & - \\
Telescopium meal & 0 & 13,75 & 27,5 & 41,25 & 55 & - \\
Wheat flour & 10 & 10 & 10 & 10 & 10 & - \\
Sagoo meal & 5 & 5 & 5 & 5 & 5 & - \\
Corn gluten meal & 10 & 10 & 10 & 10 & 10 & - \\
Coconut oil & 2 & 2 & 2 & 2 & 2 & - \\
Fish oil & 3 & 3 & 3 & 3 & 3 & - \\
Fine brain & 10 & 10 & 10 & 10 & 10 & - \\
Top Mix* & 5 & 5 & 5 & 5 & 5 & - \\
\hline Total & 100 & 100 & 100 & 100 & 100 & - \\
& Results of Proximate analysis & & & \\
\hline Fibre (\%) & 15.3 & 15.7 & 16.8 & 14.9 & 17.5 & 15.5 \\
Crude protein (\%) & 45.3 & 46.7 & 44.9 & 42.6 & 40.4 & 43.3 \\
Crude lipid (\%) & 11.9 & 9.89 & 9.09 & 8.82 & 8.68 & 7.40 \\
Moisture (\%) & 8.99 & 9.58 & 9.95 & 10.3 & 9.28 & 9.45 \\
Ash (\%) & 10.3 & 9.74 & 8.91 & 6.21 & 5.78 & 6.25 \\
BETN & 8.21 & 8.64 & 10.35 & 17.17 & 18.36 & 18.1 \\
\hline
\end{tabular}

Note : The experimental dies were analyzed in Laboratory of Fish Nutrition in Tokyo University of Marine Science and Technology, Japan

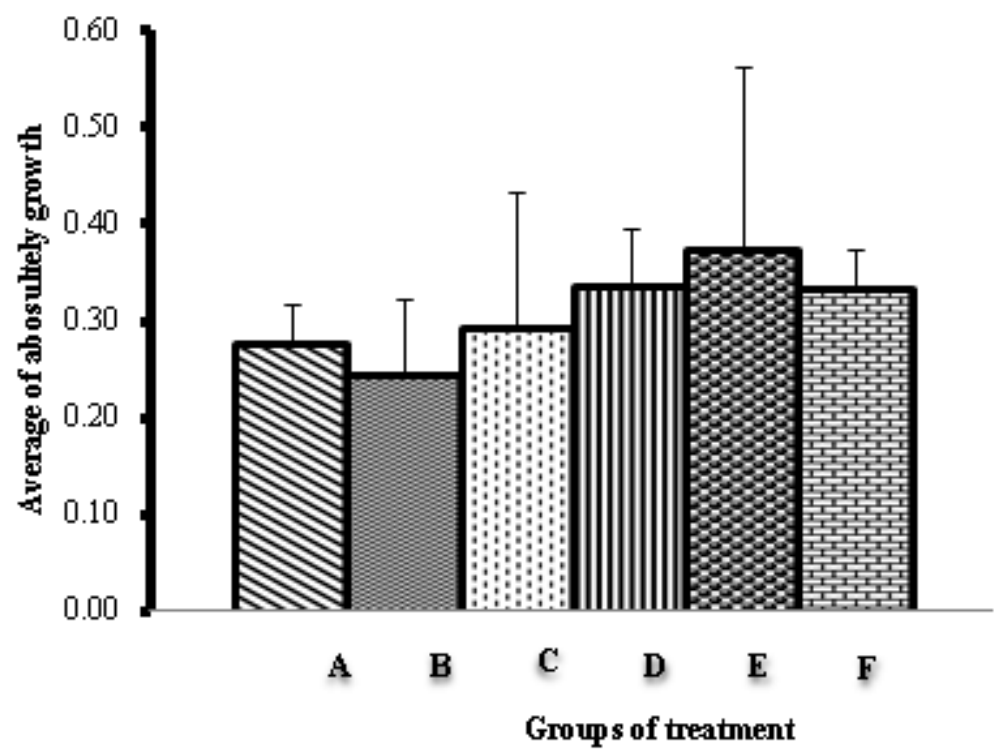

Figure 1: Average of weight gain of the shrimp at the end of experiment

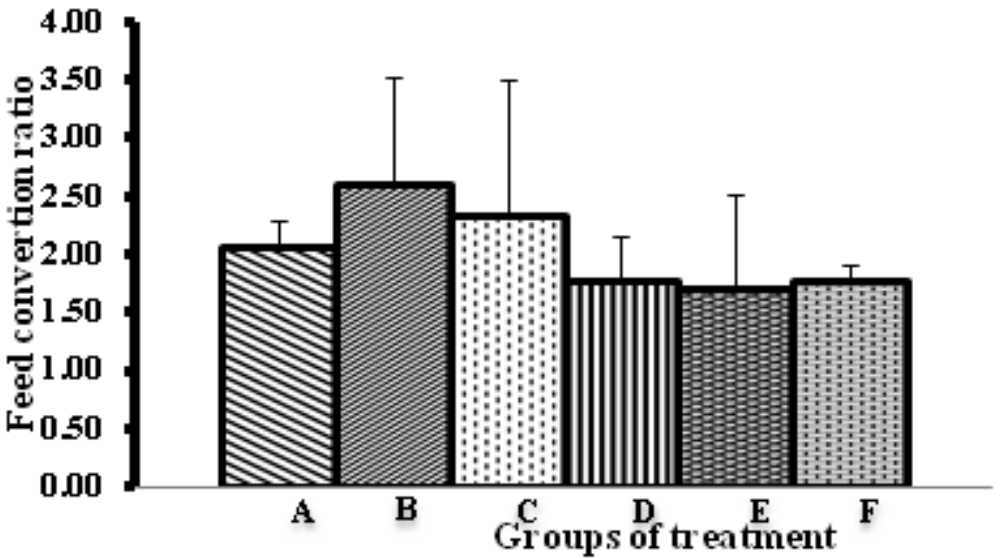

Figure 2: Feed conversion ratio of the shrimp 


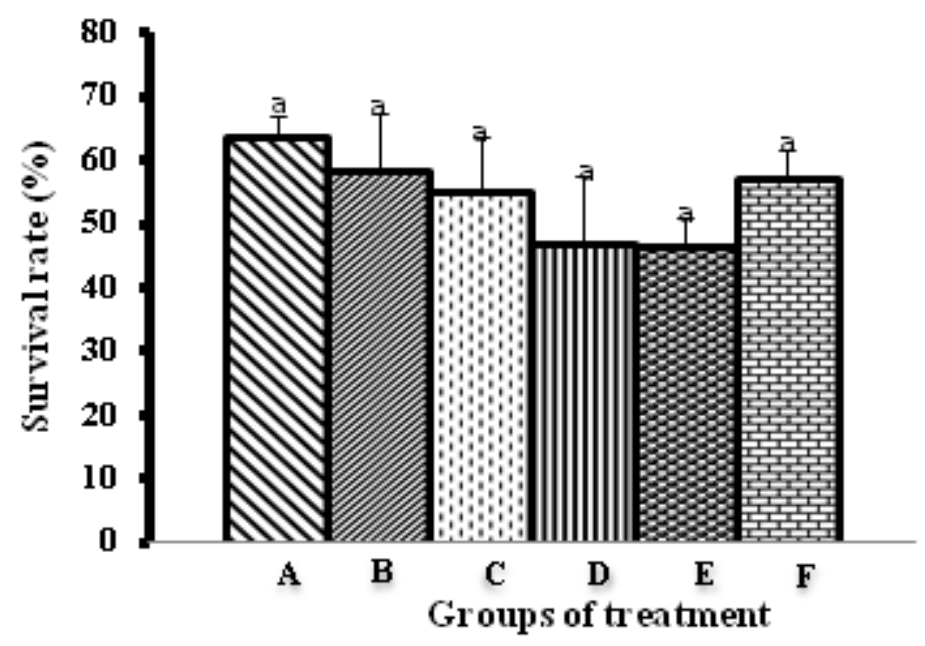

Figure 3: Survival rate of the shrimp at the end of experiment 